DOI: $10.53469 /$ jissr.2021.08(09).18

\title{
An Eco-critical Analysis of Moby Dick
}

\author{
Yue Zhao, Mengyang Zhang \\ School of Foreign Languages, Xinyang Normal University
}

\begin{abstract}
Moby Dick is well acknowledged as a world masterpiece by the American author Herman Melville. This paper attempts to analyze Melville's Moby Dick by the theory of eco-criticism. In order to better approach the American society before the 1950s, the author aims to scrutinize the novel with eco-criticism from three such aspects as nature, society and spirit so that the present society can gain some insights in preventing and solving similar problems. Divided into several parts as follows, this paper introduces Melville and Moby Dick as well as eco-criticism first and then interprets the novel via eco-criticism in three aspects, and finally ends with its realistic significance as a conclusion.
\end{abstract}

Keywords: Eco-criticism, Moby Dick, Human and nature.

\section{Introduction to Melville and His Moby Dick}

Herman Melville (1819-1891), American writer, poet, suffered an agonizing neglect by his contemporaries, but around the year of 1920 he was suddenly considered as a major American writer. He was once a sailor and his writing career benefited from it a lot because he wrote some famous works based on his sailing experiences. Besides, during his whole life he wrote a good deal more: some short stories such as Bartleby the Scrivener, quite a bit of poetry, which is now arousing increasing respect, and two celebrated novels, Benito Cereno and Billy Budd.

In 1851, Melville's masterpiece Moby Dick, also named The Whale, was published. At present, it is regarded as one of the best American novels reflecting the American society of the nineteenth century. It mainly narrates a story about a captain named Ahab together with his crew who is revenged on a huge whale and goes to ruin all of them with it, except the narrator Ishmael.

\section{Introduction to Eco-criticism}

Originated in the United States, eco-criticism belongs to one of the models of literary criticism. In the year of 1978, William Rueckert proposed to employ the term "eco-criticism". Eco-criticism is a long-term reflection of environmental problems and ecological problems in the field of literary research. It reconsiders and examines the relationship between human beings and the ecological environment from a unique ecological perspective.

In the 1990s, it began to develop like a tornado and spread to countries around the world, which made it a global phenomenon (Huang 175). With its unique characteristics, eco-criticism is quite powerful: it is not only a promise to the calling of reality, to save nature as the living environment of human, but also an effect to return humanity to nature, thus confronting the problem of human alienation. It not only takes deconstruction as a theoretical weapon, but also transcends it and becomes a constructive criticism, because its ultimate concern is to rebuild the new spiritual and material homeland of man and nature (Wei 120).

\section{Reflection in Three Aspects}

\subsection{Reflection in Nature}

With the development of American capital economy, the pursuit of people for money became the mainstream social trend during the period of the author's life time. The government advocated that people could try their best to take full advantage of resources, including the natural resources. As a consequence, countless Americans went to the oceans for the whaling, and America became the largest nation in whaling industry. The whalemen of America outnumbered all the rest of the banded whalemen in the world at that time. The prosperity of the whaling industry is illustrated by the description in Moby Dick:

Sail a navy of upwards of seven hundred vessels; manned by eighteen thousand men; yearly consuming 4,000,000 of dollars; the ships worth, at the time of sailing, $\$ 20,000,000$; and every year importing into our harbors a well reaped harvest of $\$ 7,000,000$ (Melville 109).

In order to benefit more, these whalemen sailed to every corner in the oceans to chase whales. It went without saying that the whaling industry greatly damaged the balance of the ecology in the sea, when the whale oil was transported to all parts of the world. Ahab was one of the representatives of these people at that time. He was involved in whaling at his very young age. During his whaling career over the last forty years, he brought colossal damage to nature in his own way. On the one hand, human beings fought for resources. On the other hand, they also destructed nature since Moby Dick was an embodiment of nature. Being different from human beings, Moby Dick was innocent, and did not attack people by its nature. Meanwhile, it had overwhelming power and cunning mind, defeating whalemen many times. Furthermore, Moby Dick bit off Ahab's leg which was out of defense, but Ahab wanted to kill it out of interests and revenge. After the first two failures in the conflict with it, Ahab was entirely controlled by his irrational desire-revenge, and finally went to ruin with Moby Dick as well as the whole crew. The author's idea about men and nature is further analyzed as follows: 
Melville sees the conflict between men and nature and the result of the conflict, as indicated at the end of the novel, is the destruction of both. In his opinion, the ideal way to deal with nature is to live in harmony with it instead of being against it ( $\mathrm{Li}$ 216).

\subsection{Reflection in Society}

\subsubsection{Tyranny and democracy}

Melville described many such dark qualities among the civilized men in the novel as hypocrisy, oppression and suspicion, and so on. In chapter 34, the different atmospheres at the captain's table were the vivid illustration on this point. When Ahab and his three mates were eating, there was not any noise, even any communication among them. Besides, there were also some rules followed by them. Namely, Ahab should enter the dining room first, then Starbuck the second, Stubb the third and the last one was Flask. However, even if Flask was the last one for meal, he had to leave the table before others. So Ahab always had plenty of time for his meals, while Flask was often hungry after meals.

On the contrary, the uncivilized men had good qualities in many ways. They were easy-going and very friendly to others. There was no hypocrisy in their words and actions. For instance, when Queequeg met Ishmael for the first time, within two days he began to treat Ishmael as his bosom friend, and gave the latter fifteen dollars in silver, which was his half possession.

At the captain's table, compared with the stiff atmosphere of the leaders' meal, the three harpooners did not follow any table manners. Instead they talked loudly while eating. Judging from these differences, we can see that there was more freedom among the uncivilized men than among the others.

\subsubsection{Job discrimination}

With the public's discrimination against the whalemen and Ahab's prejudice against the blacksmith, it is easy to understand the world's misunderstandings of those men participating in the menial jobs. The world enjoyed their labor and products but despised these whale hunters and blacksmiths. But butchers, also, and butchers of the bloodiest badge had been all Martial Commanders whom the world was invariably delighted to honor (Melville, 109). At this point, Melville aimed to question the public why those men killing thousands of people could enjoy great honor, whereas these men killing animals for their living could not obtain the corresponding respect from others.

\subsubsection{Racial discrimination}

Another social problem reflected in the novel is the racial discrimination in America. Although since the first batch of Europeans came to this "New Land" and claimed that this continent was God's Eden and everybody was equal here, that did not include women, black people, not to mention the native American Indians. America has not achieved its equality for everyone within its territory even till today.

In Melville's time, racial discrimination was pushed to a summit. Before him the American plantation economy had developed for nearly a century, and after him President Lincoln would abolish the slavery, so it was a severe problem at that time on how to deal with the relationships among different nations and races. In the novel, there are many places describing these phenomena, among which Ishmael's experience is just one example. When Ishmael wanted to stay for one night in Spouter Inn, as he was told he had to share one bed with a "savage", the author used immense description of Ishmael's inner thought:

Lord save me, thinks I, that must be the harpooner, the infernal head-peddler. (Melville, 28) His bald purplish head now looked for all the world like a mildewed skull. Had not the stranger stood between me and the door, I would have bolted out of it quicker than ever bolted a dinner. It was now quite plain that he must be some abominable savage or other shipped aboard of a whaleman in the South Seas, and so landed in this Christian country (Melville, 29).

Although the landlord of the inn, Peter Coffin, had told Ishmael the characteristics of Queequeg previously, he still thought this savage as a horrible image. When he met Queequeg the first time, he was almost scared to death out of control. As an ordinary person, Ishmael's attitude to a heathen represented the mainstream values for minor races. The public differentiated people by the colors of complexion or religious beliefs, which was reflected in the book clearly.

\subsection{Reflection in Spirit}

\subsubsection{Lack of spiritual independence}

Most of the workers on Pequod came from the lower classes of different countries or nations. Lacking in enough education and good upbringing, they became seamen in order to acquire the basic living materials and raise their families. The crew of Pequod was not independent on their thinking. They all followed Ahab's will, even if they had to take great risks. Only the first mate, Starbuck, could have words with Ahab, but he was often persuaded by Ahab's eloquence and authority. After the Spanish golden coin was nailed to the mast and the crew and Ahab took the oath together, the destiny of Pequod was indicated. In the later course to chase Moby Dick, the crew experienced danger several times but they could do nothing to save themselves. This was due to not only the tyranny of Ahab, but also their spiritual reliance on him. "Different from the other crew on board, Ahab has a strong desire. Driven by his desire to revenge, he considers the killing of Moby Dick as his ultimate life goal" (Huang, 226).

Therefore, Ahab took advantage of the spiritual reliance of the crew to achieve his ambition. Finally, the fate of the crew was 
tied to Pequod with Ahab's stubborn mind for revenge and they were thus ruined with Moby Dick.

\subsubsection{Lack of beliefs}

When Melville conceived his masterpiece-Moby Dick, the American industry was developing rapidly. The Americans were wholeheartedly pursuing fortune by various kinds of means, including the conquest of nature. Meanwhile, the environmental problems did not arise at the beginning, which made these civilized men more unscrupulous and flagrant. Some of them gave up their religious beliefs, and lived an aimless life, and others indulged themselves in earthly happiness.

In this book, Ahab was a typical example of these people. "Though nominally included in the census of Christendom, he was still an alien to it." (Melville, 151) Ahab did not believe in God, and even regarded himself as a deity. If Ahab had a humble heart for nature, he would not chase Moby Dick persistently, because there was a mysterious power in it. With the tempestuous weather Moby Dick turned up for the first time, so it was the symbol of nature. But no matter what it was, Ahab was determined to slay it. According to the narrator, even if the sun opposed to and hurt him, he would still revenge for himself. Therefore, when he had these ideas, he had given up his religious belief, which brought him and his crew the catastrophe.

Instead of betraying their religious beliefs like the civilized men, the uncivilized man Queequeg had his firm belief. He insisted on praying in front of his idol-a puppet. In addition, he would do a Ramadan every year, and the sufferings of his Ramadan were to sit for a whole day in a certain gesture without eating and drinking, even moving. When he fell down because of illness, he let a carpenter make a coffin for him by following his own beliefs and conventions. To everyone's surprise, he recovered on the second day. So Melville interpreted the positive effects of pious belief here, and gave his praise to those who could stick to their religious beliefs.

At that time, many people had religious dilemma, even including the calm and rational Ishmael in the book. "Ishmael is a Christian believer, but he is not sure about God's mercy and questions a lot" (Du, 168). Apparently he had the belief crisis of his own.

\subsubsection{Spiritual alienation}

Readers can also find some traces about alienation in the book. Although the three mates lived together with Ahab in his cabin, they seldom went into it and chatted with him. Even if it was time for meal, these four people called each other as a routine without any affinity. This was not peculiar to the leaders, but it was peculiar among the whole crew. There was no intimate relationship among the crew. Before Ishmael and Queequeg went aboard, they were good friends, but they seldom had chance to talk with each other after they became harpooner and sailor respectively. One of the reasons for this change was because they belonged to different groups the instant they joined the ship. The alienation exists not only in friendships and colleague relationships, but also in relatives and marriage bonds. When Ahab lost a leg, his relatives gave him neither comfort nor care but awe and alienation. Moreover, the disharmonious marriage life and long-term work far away from home made his wife alienated from him. For Ahab, he had very little attachment to his family, so it was understandable for him to take revenge on a whale madly. He had been indifferent to his life for a long time, and this was the negative influence of alienation.

\section{The Realistic Significance}

The realistic significance of Moby Dick is of great importance. According to the recent research of the novel, it contains a variety of themes that have a profound impact on future generations. That is the relationship between human and nature, human and society, and human and human, thus showing the realistic significance embodied in this work - the importance of harmony (Zhao 83).

Firstly, Melville expressed the importance of the harmony between human and nature.

Nature has endless power, and human seems unable to conquer it. It was also the author's attitude towards nature, which indicates that nature has a mysterious and frightening power. Intentions that wish to conquer it will be inevitably in vain, and at the same time nature will repay what you have done in a way of more serious punishment (Ren \&Wang 196).

But the captain of Pequod Ahab did not realize that, and took some measures to fight against nature, so he went to hell finally. That enlightens us about what we should do nowadays: When we face the problem concerning how to develop economy and protect environment, we should promote the development of economy as well as protect the environment. But when the two parties have conflicts, the latter should be given the first priority as always because "lucid waters and lush mountains are invaluable assets" said by our President Xi Jinping in 2005.

Secondly, Melville emphasized the importance of the harmony between human and society. In other words, that is the harmony among nations and races, especially among people. On the one hand, Melville described many job discriminations in the book. Those who engaged in heavy and low-paid work did not gain respect equally as others. Harpooners taking great chance with their lives could only get low pay, and the carpenters, blacksmiths and gilders could get even less. People's attitude toward each other reflected their income levels, which was caused by the job discriminations. On the other hand, white people were considered much more superior to other races, and the savages from uncivilized tribes were usually looked down upon.

Thirdly, Melville also highlighted the importance of the spiritual harmony. In the novel, only first mate Starbuck had 
his own independent thought, and could express his ideas. He warned Ahab many times and even had words with Ahab, but that did not mean he would lose Ahab's trust. Instead, Ahab respected Starbuck and did not let him take any risk when Ahab chased Moby Dick in a small boat. However, as the crew did not have the independent thought and followed Ahab's crazy ideas, they soon saw their dooms together. Another important issue is about how to remove spiritual alienation. Everyone in society should find the meaning of life. The open-minded people will value life much more and live longer than the narrow-minded ones. If there is a spiritual harmony in society, the alienation must be eliminated among human beings.

\section{Conclusion}

Through the vivid and detailed description of whaling in Moby Dick and a tragedy at the end of the novel, Melville revealed various problems in American society of the nineteenth century and expounded on the importance of achieving harmony between man and nature, man and society, and human's spirit. So the book not only offers a great deal of materials for the research of the nineteenth-century American society, but also has great value for our contemporary society. During the process of pursuing economic prosperity, people should also pay attention to nature, society and spirit in order to realize a sustainable development.

\section{References}

[1] Chang, Yaoxin. (2019). A Survey of American Literature. Tianjin: Nankai University Press.

[2] Du, Liangxia. (2015). "On the Identity of Ishmael in Moby Dick”. Overseas English, (13):167-168.

[3] Huang, Dongsheng. (2018). "A Theoretical Overview of Eco-criticism”. Contemporary Tourism, (6):175-176.

[4] Huang, Pengfei. (2019)."The Madness of Humanity - An Analysis of Moby Dick with Lacan's Desire Theory". Course Education Research, (6): 226-227.

[5] Li, Mengyu. (2012). "The Relationship between Men and Nature Reflected by the Conflict between Captain Ahab and Moby Dick". Overseas English, (12): 216-217.

[6] Li, Zhehui. (2013). "The Characters of the Captain Ahab in Moby Dick". Overseas English, (16): 230-231.

[7] Melville, Herman. (2001). The Whale [M]. Beijing: Culture and Art Press.

[8] Ren, Yueqiang, Wang Ding. (2018). “Captain's Paranoid Personality and Obtaining Principles in Moby Dick”. Overseas English, (19): 194-196.

[9] Wei, Liping. (2016). "Analysis of the 'Sea' in Robinson Crusoe and Moby Dick". Science \&Technology, (5): 221-222.

[10] Wei, Qingqi. (2003). "Ecocriticism: Concluding the Final Besiegement of Logocentrism”. Foreign Literature Studies, (4): 117-122.

[11] Zhao, Yanxia. (2010). “An Analysis of Ahab's Spiritual Ecology in Moby Dick and Its Significance”. Vocational Technology, (10): 83. 